\title{
Comparison of total laparoscopic hysterectomy and abdominal hysterectomy
}

\author{
Total laparoskopik histerektomi ve abdominal histerektominin \\ karşılaştırılması
}

\author{
Osman Balcı \\ Necmettin Erbakan University Meram Faculty of Medicine, Department of Obstetrics and Gynecology, Konya, Turkey
}

\begin{abstract}
Objective: The aim of this prospective study is to evaluate and compare to the outcomes of total laparoscopic hysterectomy (TLH) and total abdominal hysterectomy (TAH) who performed in our clinic.

Materials and Methods: We performed surgical procedures at Necmettin Erbakan University Faculty of Medicine, Department of Obstetrics and Gynecology between January 2013 and April 2014. Forty patients who underwent TLH (group 1) compared to 40 patients who underwent TAH (group 2). The mean age of the cases, body mass index (BMI), duration of operation, the amount of blood loss, rates of complications and post operative hospital stay were compared for two groups.

Results: There were no statistically significant differences between the two groups regarding age, body mass index (BMI), specimen weight, pre-operative hemoglobin $(\mathrm{Hb})$ value and rates of the complications. The mean post-operative $\mathrm{Hb}$ value was significantly higher in group 1 than group 2 (11.5 \pm 0.8 gr/ $\mathrm{dl}$ vs. $10.8 \pm 1.7, \mathrm{p}=0.02)$. The mean time of operation was significantly longer in group 1 than in group $2(105.4 \pm 22.9$ minutes vs. $74 \pm 18, \mathrm{p}<0.001)$. The mean duration of hospital stay was statistically shorter in group 1 compared to the group $2(2.48 \pm 0.6$ days vs. $4.88 \pm 1.2, p<0.001)$.

Conclusion: Total laparoscopic hysterectomy is safe and feasible method for gynecological diseases. TLH may offer specific benefits for properly selected patients. Its advantages are lower peri-operative morbidity, improvement of quality of life, shorter hospital stay and faster return to activity. J Turk Soc Obstet Gynecol 2014:4:224-7
\end{abstract}

Key Words: Total laparoscopic hysterectomy, total abdominal hysterectomy, complications

Conflict of Interest: The author reported no conflict of interest related to this article.

\section{Özet}

Amaç: Bu prospektif çalışmanın amacı, kliniğimizde gerçekleştirilen total laparoskopik histerektomi (TLH) ve total abdominal histerektomi (TAH) vakalarını değerlendirmek ve karşılaştırmaktır.

Gereç ve Yöntemler: Bu çalışma Necmettin Erbakan Üniversitesi Meram Tıp Fakültesi, Kadın Hastalıkları ve Doğum Anabilim Dalı'nda Ocak 2013 ile Nisan 2014 tarihleri arasında gerçekleştirilmiştir. TLH uygulanan 40 hasta (grup 1) ile TAH yaplan 40 hasta (grup 2) karşılaştırılmıştır. Olguların ortalama yaşı, vücut kitle indeksi (VKİ), operasyon süresi, kan kaybı, komplikasyon oranları ve ameliyat sonrası hastanede kalış süreleri iki grup arasında karşılaştırılmıştır.

Bulgular: Her iki gurupta yaş, VKİ, spesimen ağırlığı, preoperatif hemoglobin (Hb) değeri ve komplikasyon oranları arasında istatistiksel olarak anlamlı bir fark yoktu. Ortalama postoperatif Hb değeri grup l'de grup 2'den daha yüksekti ve istatistiksel olarak anlamllydı $(11,5 \pm 0,8$ gr/dl-10,8 $\pm 1,7$, p=0,02). Ortalama operasyon süresi grup'1 de grup'2 den daha uzundu ve istatistiksel olarak anlamliydı $(105,4 \pm 22,9$ dakika-74,5 $\pm 18,1, p<0,001)$. Ortalama hastanede kalış süresi grup l'de grup 2'den daha kısa ve istatistiksel olarak anlamlıydı $(2,48 \pm 0,6$ gün-4,88 $\pm 1,2, \mathrm{p}<0,001)$.

Sonuç: Total laparoskopik histerektomi jinekolojik hastalıklar için güvenli ve uygun bir yöntemdir. TLH doğru seçilmiş hastalar için özel avantajlar sunabilir. Bu avantajlar; daha düşük peri-operatif morbidite, yaşam kalitesinin iyileştirilmesi, daha kısa hastanede kalış süresi ve aktiviteye daha hızlı geri dönüştür. J Turk Soc Obstet Gynecol 2014;4:224-7

Anahtar Kelimeler: Total laparoskopik histerektomi, total abdominal histerektomi, komplikasyonlar

Çıkar Çatışması: Yazar bu makale ile ilgili olarak herhangi bir çıkar çatışması bildirmemişlerdir.

\section{Introduction}

Gynecological surgical laparoscopy started to be used by Palmer at the end of 1950s. While surgical procedures like adhesiolysis, cyst aspiration and ovarian biopsy were performed firstly, Reich et al. reported first laparoscopic assisted vaginal hysterectomy case in 1989(1). Since then, when compared with abdominal hysterectomy, because of lower morbidity and faster healing period, laparoscopic hysterectomy started to be used progressively as an

Address for Correspondence/Yazışma Adresi: Osman Balcı, MD,

Necmettin Erbakan University Meram Faculty of Medicine, Department of Obstetrics and Gynecology, Konya, Turkey

Phone: +903322237612 E-mail: drobalci@hotmail.com

Received /Geliş Tarihi : 15.05.2014

Accepted/Kabul Tarihi : 14.07.2014 
alternative of abdominal hysterectomy. But because necessity of comprehensive surgical education and equipment today still a lot of gynecologists prefer abdominal surgery. Aim of this prospective study is to evaluate and compare the results of total laparoscopic hysterectomy (TLH) and total abdominal hysterectomy (TAH) cases which were performed in our clinic.

\section{Materials and Methods}

Eighty patients who had hysterectomy operation for benign indications between January 2013 and April 2014 at Necmettin Erbakan University Meram Medical Faculty, Gynecology and Obstetrics Department are included in this study. According to which surgical procedure performed, patients are chosen consecutively and divided into two groups. While group 1 involve 40 patients who had TLH operation; group 2 involves 40 patients who had TAH operation. All of the patients had preoperative endometrial biopsy.

All of the patients were operated by same surgeon and both of these two groups had same pre-operative preparation. All of the patients were hospitalized 1 day before operation. Twentyfive $\mathrm{mg}$ oral diazepam was given each patient 2 hours before operation for premedication and operations were performed under general anesthesia. All of the patients received antibiotic prophylaxis pre and postoperative and both of these two groups received suitable analgesics for pain control. TAH was performed pfannenstiel incision with classical technique which was described for benign indications(2).

To the patients who had TLH operation, after trendelenburg position, cervical length was measured for uterine manipulation, RUMI ${ }^{\circledR}$ II (CooperSurgical, Trumbull, CT) manipulator was placed in uterine cavity. This preparation part of operation took 10 minutes. During surgery $10 \mathrm{~mm}$ telescope and advanced bipolar energy modalities were used. Including umbilicus 3 laparoscopic trocar were inserted, firstly $10 \mathrm{~mm}$ trocar was inserted directly in $1 \mathrm{~cm}$ incision which was on subumbilical area. Laparoscope was placed in abdomen after 3-4 $\mathrm{L} \mathrm{CO}_{2}$ insufflations into the abdominal cavity. Second and third incisions were made on avascular right and left lower abdomen and two $5 \mathrm{~mm}$ trocars were placed in abdomen. All relations of uterus and vaginal complex were cut by use of bipolar electrocautery same as classic laparoscopic hysterectomy. Uterus and ovaries were put out of abdomen from vagina, and if necessary intracorporeal myomectomy and morcellation was performed. With closure of vaginal cuff using laparoscopic intracorporeal approach, operation was finished. Vaginal cuff was sutured with number 0 vicryl (Ethicon, Somerville, NJ) separately and sutures were passed through right and left utero-sacral and cardinal ligaments. Operation timing was done between skin incision and last skin suture. Patients' preoperative and postoperative first day hemoglobin value was registered. Foley catheter was removed on postoperative first day. All of the patients were called for gynecological examination on postoperative $40^{\text {th }}$ day.
Groups are compared in terms of mean age, body mass index (BMI), operation time, blood loss, complication rate and postoperative hospitalization time.

Data was registered as mean \pm standard deviation and percentage. Data analysis was done with chi square and student-t tests of SPSS program. $\mathrm{p}<0.05$ value was regarded as statistically significant.

\section{Results}

Mean age and body mass index (BMI) of both of these two groups were similar and there was no statistically significant difference. There was no difference between two groups about previous abdominal surgery. Operation indications were similar for both two groups and major indication was myoma uteri. Patients' characteristics and operation indications were shown on Table 1.

Weight of surgical specimen, preoperative hemoglobin $(\mathrm{Hb})$ value and complication rates was similar for both two groups and there was no statistically significant difference. Mean postoperative $\mathrm{Hb}$ value was higher in group 1 than group 2 and this was statistically significant $(11.5 \pm 0.8 \mathrm{gr} / \mathrm{dl}-10.8 \pm 1.7, \mathrm{p}=0.02)$. Mean operation time was longer in group 1 than group 2 and this was statistically significant $(105.4 \pm 22.9$ minutes-74.5 $\pm 18.1, \quad \mathrm{p}<0.001)$. Mean hospitalization time was shorter for patients who undergone TLH (group 1) than patients who undergone TAH (group 2) and this was statistically significant $(2.48 \pm 0.6$ day- $4.88 \pm 1.2, \mathrm{p}<0.001)$. There was necessity of blood transfusion for one patient who had TLH and for two patients who had TAH, this was not statistically significant. Neither of groups had intraoperative complications, 1 patient who had TLH and 2 patients who had TAH had postoperative fever. There was no need for laparotomy about patients who had laparoscopy. Clinical results of patients are shown on Table 2.

Postoperative pathology results were reported; leiomyoma at 38 patients, serous cyst adenoma at 12 patients, adenomyosis at 10 patients, simple serous cyst and leiomyoma at 7 patients, endometrial polyp at 5 patients, endometrioma at 4 patients, non-atypical endometrial hyperplasia at 3 patients and atypical endometrial hyperplasia at 1 patient.

\section{Discussion}

Even though abdominal hysterectomy is the most frequented way of hysterectomy in the world, today we have a lot of techniques for hysterectomy. Uterus may be removed abdominal, vaginal or laparoscopic.

In a lot of studies which compare abdominal and laparoscopic hysterectomy, because of lower complication incidence and lower postoperative pain, less blood loss, shorter hospitalization period, shorter healing time and earlier turn back to daily activities laparoscopic hysterectomy is reported to have more advantages than abdominal hysterectomy(3-6).

Because of laparoscopic surgery needs experience, while laparoscopic hysterectomy cases take a long time at the 
beginning, with progressive experience operation time is getting shorter. Anyway, studies report that laparoscopic hysterectomy takes longer operation time than abdominal

Table 1. Patients' characteristics and operation indications

\begin{tabular}{llll} 
& TLH $(\mathrm{n}=40)$ & TAH $(\mathrm{n}=40)$ & p value \\
\hline Age (years) & $47.9 \pm 5.6$ & $49.5 \pm 5.3$ & 0.20 \\
\hline BMI $\left(\mathrm{kg} / \mathrm{m}^{2}\right)$ & $30.3 \pm 4.7$ & $30.7 \pm 3.8$ & 0.69 \\
\hline $\begin{array}{l}\text { Prior abdominal } \\
\text { surgery }\end{array}$ & $8(20.0 \%)$ & $6(15 \%)$ & 0.55 \\
\hline $\begin{array}{l}\text { Operation Indications } \\
\text { Myoma uteri }\end{array}$ & $16(40.0 \%)$ & $18(45.0 \%)$ & \\
\hline AUB & $6(15.0 \%)$ & $5(12.5 \%)$ & \\
\hline $\begin{array}{l}\text { Ovarian cyst } \\
\text { Adenomyosis }\end{array}$ & $5(12.5 \%)$ & $5(12.5 \%)$ & \\
\hline $\begin{array}{l}\text { Myoma+Ovarian cyst } \\
\text { Endometrial polyp }\end{array}$ & $3(7.5 \%)$ & $3(7.5 \%)$ & \\
\hline $\begin{array}{l}\text { Endometrioma } \\
\text { Non-atypical }\end{array}$ & $2(5.0 \%)$ & $2(5 \%)$ & \\
$\begin{array}{l}\text { Nondometrial } \\
\text { hyperplasia }\end{array}$ & $1(2.5 \%)$ & $1(2.5 \%)$ \\
$\begin{array}{l}\text { Atypical endometrial } \\
\text { hyperplasia }\end{array}$ & $1(2.5 \%)$ & $1(2.5 \%)$ \\
$\begin{array}{l}\text { Data are given mean } \pm \text { standard deviation or number (percentage), TLH: Total } \\
\text { laparoscopic hysterectomy, TAH: Total abdominal hysterectomy, BMI: Body mass } \\
\text { index, AUB: Abnormal uterine bleeding }\end{array}$ & \\
\hline
\end{tabular}

Table 2. Clinical results of patients

\begin{tabular}{|c|c|c|c|}
\hline & TLH $(n=40)$ & TAH $(n=40)$ & $p$ value \\
\hline Specimen weight (gr) & $218.8 \pm 117.4$ & $235.8 \pm 93.1$ & 0.47 \\
\hline $\begin{array}{l}\text { Pre-operative Hb value } \\
(\mathrm{g} / \mathrm{dl})\end{array}$ & $12.5 \pm 0.9$ & $12.8 \pm 1.7$ & 0.28 \\
\hline $\begin{array}{l}\text { Post-operative } \mathrm{Hb} \text { value } \\
(\mathrm{g} / \mathrm{dl})\end{array}$ & $11.5 \pm 0.8$ & $10.8 \pm 1.7$ & 0.02 \\
\hline Operating time (min.) & $105.4 \pm 22.9$ & $74.5 \pm 18.1$ & $<0.001$ \\
\hline $\begin{array}{l}\text { Hospitalization time } \\
\text { (day) }\end{array}$ & $2.48 \pm 0.6$ & $4.88 \pm 1.2$ & $<0.001$ \\
\hline Blood transfusion & $1(2.5 \%)$ & $2(5 \%)$ & 0.55 \\
\hline Post-operative fever & $1(2.5 \%)$ & $2(5 \%)$ & 0.55 \\
\hline Bladder injury & 0 & 0 & NS \\
\hline Bowel injury & 0 & 0 & NS \\
\hline Ureter injury & 0 & 0 & NS \\
\hline $\begin{array}{l}\text { Conversion to } \\
\text { Laparotomy }\end{array}$ & 0 & 0 & NS \\
\hline \multicolumn{4}{|c|}{$\begin{array}{l}\text { Data are given mean } \pm \text { standard deviation or number (percentage). TLH: Total } \\
\text { laparoscopic hysterectomy, TAH: Total abdominal hysterectomy, } \\
\text { Hb: Hemoglobin, NS: Not significant }\end{array}$} \\
\hline
\end{tabular}

hysterectomy. Olsson et al. and Härkki-Sirén et al. and Çelik et al. reported correspondingly that operation time for TLH is statistically significant longer than $\mathrm{TAH}^{(7-9)}$. But Seracchioli et al. reported no statistically significant difference about TLH and TAH operation time at their clinical trial which includes 122 women who have bigger uterus than $14^{\text {th }}$ gestational week(10). Similarly, Ribeiro et al. found out operation time shorter for vaginal hysterectomy, found out no difference between TAH and TLH in their randomized prospective study which consisted of 60 patients and compared abdominal, vaginal and laparoscopic hysterectomy(11). In our study operation time was longer for patients who had TLH than patients who had TAH and this was statistically significant.

In a lot of studies intraoperative and perioperative blood loss in laparoscopic hysterectomy was less than abdominal hysterectomy $(7,12-14)$. Raju and Auld, Çelik et al., Seracchioli et al. and Ribeiro et al. found out no statistically significant difference about blood loss between TLH and TAH(5,9-11). In our study postoperative hemoglobin value was higher in TLH patients than TAH patients and this was statistically significant. When compared with open surgery procedures, laparoscopic surgery probably because of less tissue trauma and less inflammatory response, is related with less postoperative pain and shorter healing period $(4,5,7,8,12-16)$. Also, studies show that postoperative hospitalization time is shorter in laparoscopy group $(7-9,14)$. Like other studies, in our study postoperative hospitalization period is statistically significant shorter in laparoscopy group.

Complication rate in laparoscopic hysterectomy is close to other surgical procedures. Olsson et al. couldn't find out statistically difference between complication rates of TLH and TAH in their study which compared $71 \mathrm{TLH}$ and $72 \mathrm{TAH}$ cases and also Çelik et al. couldn't find out statistically significant difference in their study which compared $47 \mathrm{TLH}$ and $30 \mathrm{TAH}$ cases $(7,9)$. In the meta analysis of randomized controlled trials which Johnson et al. reported, when compared with abdominal hysterectomy, laparoscopic hysterectomy cases have more urinary tract injuries, but there is no statistically significant difference about other visceral organ injuries(17). Garry et al. reported in their eVALuate trial, in which 1380 women included, laparoscopic hysterectomy is related with more complications than abdominal hysterectomy(18). In our study any introperative complication wasn't seen in both TLH group and TAH group. But 1 patient from TLH group and 2 patients from TAH group had postoperative fever.

In conclusion, laparoscopic hysterectomy is a safe and suitable procedure for chosen patients. It affords patients advantages like less peri-operative morbidity, better life quality, shorter hospitalization time, and faster return to activity.

\section{References}

1. Reich H. New techniques in advanced laparoscopic surgery. Baillieres Clin Obᄀstet Gynaecol 1989;3:655-81. 
2. Mattingly RF, Thompson JD. Leiomyomata uteri and abdominal hysterectomy for benign disease. In Te Linde's Operative Gynecology, 6th ed. Edited by RF Mattingly, JD Thompson. Philadelphia, JB Lipincott, 1985, pp 230-42.

3. Liu CY. Laparoscopic hysterectomy. Report of 215 cases. Gynecol Endosc 1992;1:73-7.

4. Phipps JP, John M, Nayak S. Comparison of laparoscopic assisted vaginal hysterectomy and bilateral salpingo-ophorectomy with conventional abdominal hysterectomy and bilateral salpingoophorectomy. Br J Obstet Gynaecol 1993;110:698-700.

5. Raju KS, Auld BJ. A randomized prospective study of laparoscopic vaginal hysterectomy versus abdominal hysterectomy each with bilateral salpingo-oophorectomy. $\mathrm{Br} \mathrm{J}$ Obstet Gynaecol 1994;101:1068-71.

6. Reich H, Ribeiro SC, Vidali A. Hysterectomy as a treatment for dysfunctional uterine bleeding. Baillier es Best Pract Res Clin Obstet Gynaecol 1999;13:251-69.

7. Olsson JH, Ellstro“m M, Hahlin M. A randomized prospective trial comparing laparoscopic and abdominal hysterectomy. Br J Obstet Gynaecol 1996;103:345-50.

8. Härkki-Sirén P, Sjöberg J, Toivonen J, Tiitinen A. Clinical outcome and tissue trauma after laparoscopic and abdominal hysterectomy: a randomized controlled study. Acta Obstet Gynecol Scand 2000;79:866-71.

9. Çelik C, Abali R, Tasdemir N, Aksu E, Çalışkan H, Akkuş D. Total Laparoskopik Histerektomi ve Abdominal Histerektomi Karşlaştırılması; Klinik Sonuçlar. JCAM 2014 Published online. DOI: 10.4328/JCAM.1513.

10. Seracchioli R, Venturoli S, Vianello F, Govoni F, Cantarelli M, Gualerzi $\mathrm{B}$, et al. Total laparoscopic hysterectomy compared with abdominal hysterectomy in the presence of a large uterus. J Am Ass Gynecol Laparosc 2002;9:333-8.
11. Ribeiro SC, Ribeiro RM, Santos NC, Pinotti JA. A randomized study of total abdominal, vaginal and laparoscopic hysterectomy. Int J Gynaecol Obstet 2003;83:37-43.

12. Howard FM, Sanchez R. A comparison of laparoscopic assisted vaginal hysterectomy and abdominal hysterectomy. J Gynecol Surg 1993;9:83-90.

13. Nezhat F, Nezhat C, Gordons S, Wilkins F. Laparoscopic versus abdominal hysterectomy. J Reprod Med 1992;37:247-50.

14. Perino A, Cucinella G, Venezia R, Castelli A, Cittadini E. Total laparoscopic hysterectomy versus total abdominal hysterectomy: an assessment of the learning curve in a prospective randomized study. Hum Reprod 1999;14:2996-9.

15. Ellstro"m M, Bengtsson A, Tylman M, Haeger M, Olsson JH, Hahlin M. Evaluation of tissue trauma after laparoscopic and abdominal hysterectomy: measurements of neutrophil activation and release of interleukin-6, cortisol, and C-reactive protein. J Am Coll Surg 1996;182:423-30.

16. Labib M, Palfrey S, Paniagua E, Callender R. The postoperative inflammatory response to injury following laparoscopic assisted vaginal hysterectomy versus abdominal hysterectomy. Ann Clin Biochem 1997;34:543-5.

17. Johnson N, Barlow D, Lethaby A, Tavender E, Curr L, Garry R. Methods of hys-terectomy: systematic review and meta-analysis of randomized controlled trials. BMJ 2005;330:1478.

18. 18-Garry R, Fountain J, Mason S, Hawe J, Napp V, Abbott J, Clayton R, Phillips G, Whittaker M, Lilford R, Bridgman S, Brown J. The eVALuate study: two parallel randomised trials, one comparing laparoscopic with abdominal hysterectomy, the other comparing laparoscopic with vaginal hysterectomy. BMJ 2004;328:129. 